\title{
Antecedents of corporate entrepreneurship
}

\author{
R. van Wyk* and M. Adonisi \\ Gordon Institute of Business Science (GIBS), \\ PO Box 787602, Sandton, Republic of South Africa \\ vanwyk.rene@gmailcom
}

Received March 2012

\begin{abstract}
Businesses should strive to identify and nurture internal organisational factors that cultivate a dynamic entrepreneurial culture. This paper scrutinizes the contribution of the internal organisational factors, measured by market orientation, flexibility and job satisfaction, to intrapreneurship, as measured by the Corporate Entrepreneurship Assessment Instrument (CEAI). Information from a sample of 333 managers explores the relationships of corporate entrepreneurship with different work variables by means of Product-Moment Correlation, Multiple Regression Analyses and Structural Equation Modelling. Structural Equation Modelling confirms that four of the corporate entrepreneurship factors were predicted reasonably well by means of the market orientation, flexibility and job satisfaction sub-scales. The article attempts to fill the research gap of identifying which market orientation, flexibility and job satisfaction factors play an important role in facilitating corporate entrepreneurial actions.
\end{abstract}

*To whom all correspondence should be addressed.

\section{Introduction}

Continuous economic environmental changes force businesses to nurture their entrepreneurial environment in order to secure global competitiveness, growth and survival. There is a continuous need for research that identifies the factors that contribute to the development and growth of entrepreneurial ventures (Bolton \& Lane, 2012). Organisations should proactively identify and strategically align internal factors that could increase corporate entrepreneurial performance (Barrett, Balloun \& Weinstein, 2012). Dramatic global economic forces pressurise businesses to be vigilant of threats and to act swiftly operationally (Kuratko, 2011). Businesses therefore have to continually re-examine their market orientation strategies and adapt flexible policies in serving different stakeholders. Managers and business leaders have a huge responsibility to establish and maintain corporations, sustain their functional success (Heil, Maxwell \& Whittaker, 2003) and maintain organisational performance (Fontannaz \& Oosthuizen, 2007). However, business leaders often fail to identify the factors that lead to business performance and strategise accordingly (Barrett et al., 2012).

Business growth strongly depends on corporate entrepreneurship (Antoncic \& Antoncic, 2011a). The cultivation of entrepreneurship, the driving force in established organisations (O'Connor \& Yamin, 2011) plays an important role in organizational progress and performance (Antoncic \& Antoncic, 2011b) and in sustaining a competitive advantage (Kuratko, 2009). Corporate entrepreneurial processes are necessary for continuous renewal and innovative processes to secure higher levels of efficiency and performance (Lee, Peris-
Ortiz \& Fernández-Guerrero, 2011). Entrepreneurial regeneration therefore is imperative, especially seen in the light of the world economic deterioration and increased unemployment (Van Wyk \& Adonisi, 2011).

Corporate entrepreneurship is however not an isolated factor that contributes to business innovation, but it is the result of the collective efforts of members of an organisation (Akehurst, Comeche, \& Galindo, 2009). The three key leadership factors that play an important role in the maintenance of corporate entrepreneurship, are firstly management style and orientation, secondly taking proactive action and thirdly, engaging in innovative behaviour (Goosen, De Coning \& Smit, 2002a; Goosen, De Coning \& Smit, 2002b). These factors significantly contribute to the financial performance of a firm (Goosen et al., 2002a). Entrepreneurial leadership is provided through a visionary approach and by making appropriate structures available for the facilitation and implementation of new ideas (Visser, de Coning \& Smit, 2005).

The deliberate design of corporate entrepreneurial antecedents does not always deliver the desired outcomes (Goodale, Kuratko, Hornsby \& Covin, 2011). The context in which a business operates can either advance or limit the entrepreneurial actions in a business (Welter \& Smallbone, 2011). Therefore, management should use a variety of complementary mechanisms to facilitate intrapreneurial prospects in an organisation (Goodale et al., 2011). An awareness of environmental changes and an accurate response, is critical to the survival of companies (Jafari, Rezaeenour, Mazdeh \& Hooshmandi, 2011). Business leaders should understand, and better still, anticipate how these changes transform the entrepreneurial landscape in 
which they operate. Management should furthermore promote corporate entrepreneurial activities and create an ideal work environment through open communication networking, supported by resource management practices (Castrogiovanni, Urbano \&Loras, 2011).

The essence of corporate entrepreneurship is the creation of an environment that fosters corporate thinking and behaviour (Antoncic \& Hisrich, 2001; Goosen et al., 2002a). A number of theories on corporate entrepreneurship agree on the importance of the facilitation of intrapreneurship and its influence on corporate performance and innovation (Hornsby, Naffziger, Kuratko \& Montagno, 1993; Morris \& Kuratko, 2002). Businesses should pay as much attention to internal organizational strategies in cultivating a creative culture as they do to external economic, consumer and competitive factors (Barrett et al., 2012). Key concepts that have shown to contribute to a creative climate of business performance are corporate entrepreneurship (Barrett \& Weinstein, 1997; Barrett et al., 2012), market orientation (Barrett, Balloun \& Weinstein, 2009; Barrett et al., 2012; Jaworski \& Kohli, 1996), organisational flexibility (Barrett \& Weinstein, 1997; Barrett et al., 2009; Barrett et al., 2012) and job satisfaction (Jaworski \& Kohli, 1990; Van Wyk \& Adonisi, 2008).

In practice, corporate entrepreneurship needs to be supported by a pro-active market orientation (Barrett \& Weinstein, 1997) and flexible management practices (Bhardwaj, Sushil \& Momaya, 2007). The symbiotic relationship that exists between entrepreneurship and marketing activities allows businesses to be proactive and innovative (Barrett et al., 2009). Furthermore, entrepreneurship and flexibility complement each other in maintaining a competitive advantage and creating superior value in a global economy (Rundh, 2011), as it aids businesses in being proactive in dynamic competitive environments (Miles \& Darroch, 2006), and in turbulent markets and variable conditions (Bhattacharya \& Giapponi, 2007; Hitt, Ireland, Camp \& Sexton, 2002; Oke, 2005). In addition, job satisfaction plays an important role in the relationships among corporate entrepreneurship, market orientation and flexibility (Van Wyk \& Adonisi, 2008).

The aim of this study is to explore the prediction of corporate entrepreneurship as dependent variable by means of market orientation, flexibility and job satisfaction as independent variables.

\section{Literature review}

Corporate entrepreneurship is an important facet of strategic renewal, profitability, innovativeness and growth of organisations (Drucker, 2007; Morris, Kuratko \& Covin, 2008). Although there is no general agreed definition of corporate entrepreneurship (Sharma \& Chrisman, 1999) there is consensus that corporate entrepreneurship is characterised by (1) the birth of new businesses within existing businesses, (2) the transformation or rebirth of organisations through a renewal of key areas of businesses, and (3) the innovation and renewal within an existing organisation. The strategic entrepreneurial orientation in businesses creates proactive innovativeness and risk-taking behaviour (Lumpkin \& Dess, 1996, Zahra \& Covin, 1995) which leads to strategic renewal and development of new business ventures (Guth \& Ginsberg, 1990; Zahra, 1993).

Higher levels of corporate entrepreneurship are associated with higher levels of competitiveness (Bhardwaj et al., 2007), performance, growth and the survival of firms (Covin, Green \& Slevin, 2006). For this reason, it is important to establish which factors contribute significantly to the corporate entrepreneurial functioning of a firm. The collaboration of different work teams within a firm can lead to different forms of entrepreneurial behaviour (Bojica, Del Mar Fuentes \& Gomez-Gras, 2011). It is important for businesses to nurture the entrepreneurial attitude of employees to facilitate corporate entrepreneurial behaviour (Van Wyk \& Boshoff, 2004). The sharing and facilitation of knowledge and expertise can create a strategic advantage in organisations (Leibold, Voelpel \& Tekie, 2004). It is, however, not always clear which organisational resources and capacities support entrepreneurial resourcefulness (Phan, Wright, Ucbasaran \& Tan, 2009). For this reason, the current study is an investigation into the influence of market orientation, flexibility and job satisfaction on corporate entrepreneurship.

\section{Corporate entrepreneurship and market orientation}

Research has shown that market orientation forms a direct link with corporate entrepreneurship and provides the basis for a sustainable competitive advantage (Barrett \& Weinstein, 1997). However, the literature indicates that the relationship between corporate entrepreneurship and market orientation is poorly understood (Baker \& Sinkula, 2009; Merlo \& Auh, 2009). Market orientation refers to the organisation-wide collection, responsiveness and utilization of market intelligence and the dissemination opportunities and strategies across departments (Kohli \& Jaworski, 1990; Jaworski \& Kohli, 1996). A proactive market orientation indicates a willingness to adjust to the envisaged varying future needs of customers (Atuahene-Gima et al. 2005). Market orientation thus promotes the maintenance of a competitive tactics (Zachary, McKenny, Short \& Payne, 2011) and drives innovative incentives (Zortea-Johnston, Darroch \& Matear, 2012). Market orientation is a cultural orientation that guides strategies in response to threats and opportunities in the market (Cambra-Fierro, Hart, PoloRedondo, Fuster-Mur, 2012) and fosters sustainable advantage by creating superior values for customers (Slater \& Narver, 1994) consequently achieving improved financial results (Loubser, 2000). It is the vital link in activating the organisation to react to threats and opportunities in the environment (Kumar, Subramanian \& Strandholm, 2003) with the primary objective of delivering superior customer value (Jimenez-Zarco, Martinez-Ruiz \& Izquierdo-Yusta, 2011).

Market orientation, in joint relationship with entrepreneurial leadership, advances firm performance ( $\mathrm{Li}, \mathrm{Zhao}, \mathrm{Tan}, \&$ Liu, 2008; Van Zyl \& Mathur-Helm, 2007). When market orientation and entrepreneurial orientation are in harmony, it results in an opportunistic culture that boosts profitability 
(Baker \& Sinkula, 2009). This harmony is due to the synchronising of customer and competitor intelligence of market planning, strategic exploitation of opportunities, and careful calculation of risks and uncertainties (Baker \& Sinkula, 2009; Barrett et al., 2012). In order to be truly entrepreneurial and excel in innovativeness, business should engage in parallel proactive market orientation activities (Renko, Carsrud \& Brännback, 2009). The constant scanning for market knowledge is critical in maintaining an incremental entrepreneurial orientation and translating it into higher performance (Bojica et al., 2011).

Market orientation goes beyond the collection and dissemination of information. Market orientation is a coordinated response to opportunities and threats, adding value to customer needs (Kumar et al., 2003). Both customer and competitor orientations have a significant influence on business performance (Kumar et al., 2003). A proactive market orientation leads to positive results in the short- and long-term performance of businesses, facilitating forward planning, especially in turbulent times (Kumar, Jones, Venkatesan \& Leone, 2011). Nurturing a market orientation enables businesses to operate proactively, rather than reactively in securing their competitive status (Kumar et al., 2011).

A significant positive relationship is reported between market orientation and entrepreneurial orientation in a study of 88 small firms in San Diego (Baker \& Sinkula, 2009) as well as 695 participants from different industries (Barrett et al., 2012). The practicing of market orientation and corporate entrepreneurship should be seen in perspective to enable businesses to acquire knowledge of market conditions and make appropriate decisions (Maatoofi \& Tajeddini, 2011). Flexibility and marketing goes hand-inhand and businesses have to adapt to variable consumer needs to maintain competitiveness and profitability (Hart, 2003). We are of the opinion that businesses that seek higher forms of entrepreneurship and have an active market orientation, need to adopt a flexible character in order to function harmoniously and effectively. For the purposes of the current study market orientation is seen in the view of Kumar et al. (2003, 2011), as the proactive generation of intelligence that leads to responsiveness to threats and opportunities, managed by the dissemination of intelligence.

\section{Corporate entrepreneurship and flexibility}

The highly complex environments in which businesses operate require planning systems that are flexible in order to allow frequent changes (Kukalis, 1989: 567) and meet varying needs in the market (Rundh, 2011). Flexibility is defined as the extent to which the different business units react efficiently supported by administrative relations and situational proficiency (Barrett et al., 2012; Barrett \& Weinstein, 1997). Rundh (2011) defines flexibility as the ability of a firm to respond and introduce change, while Barrett et al. (2009) describes it as a firm's ability to adapt administratively to situational knowledge. Strategic flexibility is seen as the capacity of a business to maintain competitiveness by continually adapting or responding to changing competitive environments (Hitt, Keats \& DeMarie, 1998).
Flexibility is vital for higher forms of innovation to take place (Ngamsirijit, 2010) while ensuring adaptability with improved performance (Bhattacharya \& Giapponi, 2007; Kaiser \& Overfield, 2010) and competitiveness (Horwitz, Allan, Brosnan \& Walsh, 2000). Business leaders should manage flexibility in order to reduce their vulnerability and adjust to dynamic environments (Koornhof, 2001). Flexibility is needed to cope with uncertainties and dynamic processes that take place in vigorous lucrative environments (Buganza, Gerst \& Verganti, 2010; Hoskisson \& Busenitz, 2002) to retain entrepreneurial momentum (Enderwick \& Ronayne, 2004). Firms that show low flexibility are seen as rigid in their administrative relations by strictly adhering to bureaucratic practices (Khandwalla, 1977, 1987; Miles \& Snow, 1978; Barrett \& Weinstein, 1997), thus preventing the development of new resources and capabilities, inhibiting competitiveness (Ireland, Hitt \& Sirmon, 2003). Sufficient flexibility should be allowed in order to adapt efficiently and increase organisational resilience (Ignatiadis, 2007), especially where complex processes are involved in new product development (Buganza et al., 2010). Turbulent markets require an integrated responsiveness, supported by flexible practices, to adapt competently and maintain international competitiveness (Georgoulias, Papakostas, Chryssolouris, Stanev, Krappe \& Ovtcharova, 2009; Hitt et al., 1998). Businesses should however not be too lenient on control systems when applying flexibility practices (Ignatiadis, 2007).

A flexible structural design is likely to encourage free and open discussion of ideas among employees, which is helpful in the successful development of innovative intrapreneurial ventures (Jaworski \& Kohli; 1996; Van de Ven \& Poole, 1995). The creation of an entrepreneurial milieu is not achieved by the implementation of rules, because it is largely a spontaneous process - it is by nature an adaptable flexible process (Chung \& Gibbons, 1997). Additionally the dissemination of marketplace information requires flexible practices in order to filter through cross-functional boundaries (Miles \& Snow, 1978; Child \& McGrath, 2001). In this way firms are able to react swiftly to customer needs and market opportunities while avoiding risks (Enderwick \& Ronayne, 2004). Changing customer demands and market responsiveness have to be met with flexible business policies which is essential to internationalisation of business (Rundh, 2011). In a study of 476 businesses in Nigeria it was found that strategic flexibility was significantly positively related to market performance (Olalekan, 2011). Barrett et al. (2012) report a significant positive correlation between flexibility, corporate entrepreneurship and organisational performance in a sample of 695 participants from different industries.

A flexible response is of strategic importance in a competitive environment. This research will adopt a combination of descriptions of flexibility, namely: the ability of a business to maintain competitiveness and initiate change (Rundh, 2011) by means of efficient administrative support (Barrett et al., 2012) in reaction to situational knowledge (Barrett et al., 2009). 


\section{Corporate entrepreneurship and job satisfaction}

Job satisfaction is the positive emotional state an individual experiences in the work situation (Locke, 1976). Job satisfaction is also seen as the difference between what the worker's idea of an ideal work situation is and what he actually experiences (Diener, Emmons, Larsen \& Griffin, 1985; Locke, 1976). It is the degree to which an individual's expectations of the job conforms to job experiences, influencing the overall attitude and performance of the individual (Spector, 1997), affecting the well-being of an organisation as a whole (Spector, 2008). It is important that members of corporate entrepreneurial teams experience job satisfaction, as satisfied team members will probably be more committed to team efforts and less likely to quit their jobs (Akehurst et al., 2009). High levels of job satisfaction could benefit the overall performance of a business, while low levels of job satisfaction could cripple the functioning of an organization (Galup, Klein \& Jiang, 2008). A lack of job satisfaction in an entrepreneurial team may lead to a lack of participation in marketing activities and intrapreneurship (Akehurst et al., 2009).

Kuratko, Hornsby and Bishop (2005) found that the corporate entrepreneurial factors of work discretion and rewards/reinforcement resulted in increased perceived job satisfaction, leading in turn to increased entrepreneurial actions. The study implies that job satisfaction plays a mediating role in entrepreneurial actions and business performance Job satisfaction of employees is vital in sustaining businesses and economies and the basis of business performance (Antoncic \& Antoncic, 2011b). Many studies confirm the positive relationship between job satisfaction and corporate entrepreneurship (Akehurst et al., 2009; Antoncic \& Antoncic, 2011b; Comeche \& Loras, 2010; Kuratko et al., 2005; Van Wyk \& Adonisi, 2008) and its importance as antecedent of the growth of a firm (Akehurst et al., 2009; Antoncic \& Antoncic, 2011a). In this investigation the measurement of job satisfaction takes into account both the internal job satisfaction experience, as well as the external job satisfaction conformation of expectations.

We maintain that a healthy responsive market orientation flexible policies and heightened job satisfaction should lead to advanced corporate entrepreneurship. The current study seeks to ascertain the impact of market orientation, organisational flexibility, and job satisfaction on corporate entrepreneurship in a South African context. The relationship between the different factors are conceptualised in Figure 1:

\section{Research purpose}

In the light of the argument of Goodale et al. (2011) that the deliberate design of antecedents to corporate entrepreneurship does not always deliver the desired outcomes, this study investigates the precipitating contribution of market orientation, flexibility and job satisfaction to the manifestation of corporate entrepreneurship with the work variables.
The question remains to what degree market orientation, job satisfaction and flexibility contributes to corporate entrepreneurship as a dynamic process. Seen in the light of the importance of corporate entrepreneurship for business growth and implicitly economic growth, this study investigates the relationship of corporate entrepreneurship with biographic variables and the business variables of market orientation, job satisfaction and flexibility, leading to the following research questions:

1. What is the relationship between corporate entrepreneurship, market orientation, job satisfaction and flexibility?

2. To what extent do market orientation, job satisfaction and flexibility predict corporate entrepreneurship?

\section{Methodology}

Survey research was done on a non-random quota convenience sample, as described by Cooper and Schindler (2008). Individuals were selected from four different economic sectors in South Africa. A self-administered questionnaire was circulated to a selected sample of managers and supervisors from a life insurance company, information and technology firm, university of technology and parastatal in the transport sector. The questionnaire contained an introductory letter, biographic questionnaire, as well as different psychometric instruments measuring corporate entrepreneurship, market orientation, job satisfaction and flexibility. A total of 396 questionnaires were received. Thirty-six questionnaires were discarded because one or more items in the psychometric questions were not completed. This left 333 participants for the analyses.

\section{Participants}

A non-random convenience sample was selected from four different economic sectors: life insurance $(\mathrm{N}=266)$, information technology $(\mathrm{N}=33)$, a university of technology $(\mathrm{N}=26)$ and a transport parastatal $(\mathrm{N}=8)$. Only 333 of the 396 responses were usable because some of the items on the psychometric instruments were not completed. The sample consisted of 144 males and 187 females, two responses on gender were incomplete. The age of the participants ranged from 21 to 70 years, with a mean of 36,66 and standard deviation of 9,26 years. Most of the participants were married (194), constituting 58,25\% of the sample, 82 unmarried, seven widowed, 36 divorced, 11 co-habiting, one estranged and two individuals did not indicate their marital status. The largest part of the sample indicated English as their home language (202), followed by Afrikaans (86), and other African languages (45). The nationality of the respondents was mainly South African (326), four nonSouth African, and three individuals did not indicate their nationality. The respondents indicated their academic qualifications as follows: secondary school without Grade 12 (46), Grade 12 (87), post-school certificate/diploma (105), Bachelor's degree (38), Honours (33) and Master's (17), while seven did not give an indication of their academic training. 


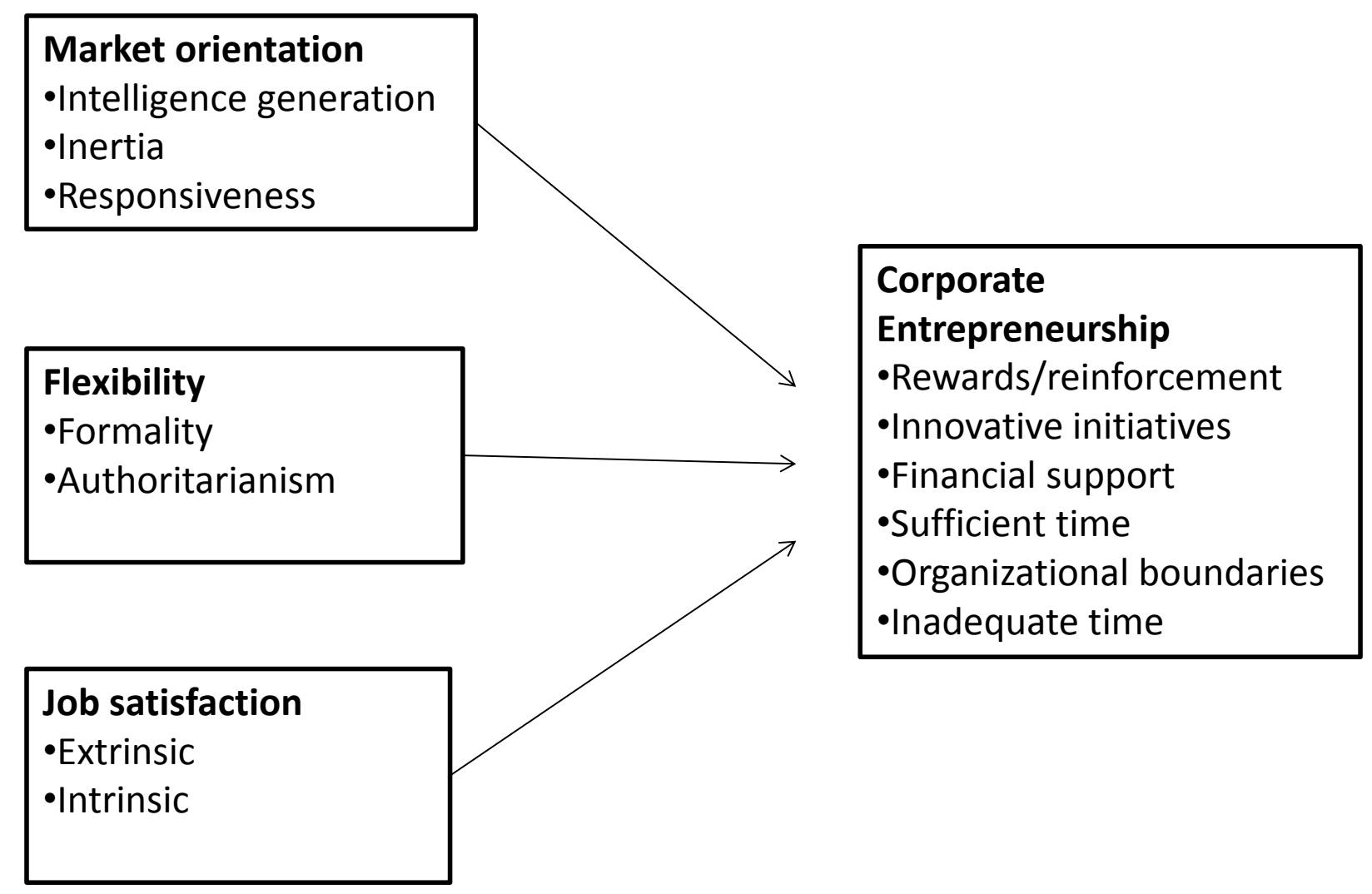

Figure 1: The relationship between the different factors of market orientation, flexibility and job satisfaction with the corporate entrepreneurial variables

\section{Measuring instruments}

Because psychometric instruments are not always portable between cultures, the construct validity of the instruments was evaluated in the current study. It is of particular importance to substantiate the construct validity of an instrument to prevent invalid and erroneous results and conclusions (Boshoff, 2009). The construct validity of each of the instruments was evaluated by means of Principal Factor Analysis with direct quartimin rotation of the axis on all the responses followed by confirmatory factor analyses (Van Wyk \& Adonisi, 2011). The alpha coefficients of the factors of the different instruments are reported as described by the different authors, followed by the re-validation for the current study.

The Corporate Entrepreneurial Assessment Instrument (CEAI) developed by Hornsby, Kuratko and Zahra (2002) measured corporate entrepreneurship. The instrument consists of 48 items, which included 11 negatively worded items, to prevent response set. The different items are measured on a Likert-type scale varying between 1 (strongly disagree) to 5 (strongly agree). The original development of the CEAI consisted of five factors, namely Management support, Work discretion, Rewards/reinforcement, Time availability and Organizational boundaries (Hornsby et al., 2002). The Organizational boundaries factor did not replicate in a re-evaluation of the CEAI (Hornsby, Holt \& Kuratko, 2008). A four-factor solution was indicated as Work discretion, Time availability, Management support and Reward/reinforcement. A re-evaluation of the CEAI in a
South African sample by means of principal factor analysis indicated an eight-factor solution. The factors were named as (Cronbach Alphas in brackets): Work discretion $(0,84)$, Management support and risk-taking $(0,82)$, Rewards and reinforcement $(0,75)$, Innovative initiatives $(0,84)$, Financial support (0,73), Sufficient time $(0,76)$, Organizational boundaries $(0,81)$ and Inadequate time $(0,67)$ (Van Wyk \& Adonisi, 2011).

The MARKOR instrument developed by Kohli, Jaworski and Kumar (1993) measured three factors of market orientation by means of a 32-item seven-point Likert scale ranging from strongly disagree to strongly agree. The three factors of intelligence generation, intelligence dissemination and responsiveness had goodness-of-fit indices of between 0,656 and 0,740 . Principal factor analysis in the current study indicated a three-factor solution with acceptable Alpha coefficients (in brackets), named intelligence generation $(0,81)$, inertia $(0,83)$, and responsiveness $(0,74)$ with goodness-of-fit indices between 0,971 and 0,990 .

Organisational flexibility was measured by means of Khandwalla's $(1977,1987)$ organisational flexibility scale. The instrument was measured on a seven-point Likert scale with varying descriptions for each item. This scale was indicated as having one factor and the psychometric properties where not provided (Khandwalla, 1977, 1987). A re-evaluation of the flexibility instrument in the current study indicated a two-factor solution, namely formality and authoritarianism. The Cronbach Alpha coefficients were 
respectively 0,81 and 0,64 with goodness-of-fit indices ranging between 0,971 and 0,989 .

The 20-item Minnesota Job Satisfaction Questionnaire (Weiss, Dawis, England \& Lofquist, 1967) measured job satisfaction on a five-point Like $t$ scale ranging from very dissatisfied to very satisfied. The authors reported the instrument consisting of two factors, namely intrinsic and extrinsic job satisfaction, with alpha coefficients of respectively 0,86 and 0,80 . The principal factor analysis of the current study replicated the two factors of extrinsic and intrinsic job satisfaction with alpha coefficients of respectively 0,86 and 0,85 and goodness-of-fit indices ranging between 0,958 to 0,984 .

\section{Empirical results}

The first research question concerning the relationships between corporate entrepreneurship and psychometric variables of market orientation, job satisfaction and flexibility was investigated by means of Pearson Product Moment correlations (see Table 1).

Pearson Moment Correlations indicated significant positive correlations between extrinsic job satisfaction and the corporate entrepreneurship sub-scales of work discretion, rewards, and innovative initiatives. The market orientation sub-scales of intelligence generation and responsiveness each correlated significantly positively with the corporate entrepreneurship sub-scales of management support and risk acceptance, and rewards. Responsiveness correlated significantly positively with innovative initiatives and financial support. Intrinsic job satisfaction correlated significantly positively with the sub-scales of corporate entrepreneurship work discretion and rewards. Extrinsic job satisfaction correlated significantly positively with the corporate entrepreneurship sub-scales of work discretion and rewards. The flexibility sub-scale formality correlated significantly positively with management support and risk acceptance, and innovative initiatives. The flexibility subscale authoritarianism correlated significantly negatively with the corporate entrepreneurship sub-scale of sufficient time.

The second research question was answered by means of Multiple Regression Analysis followed up by Structural Equation Modelling. The Multiple Regression Analyses with the eight corporate entrepreneurship scales as dependent variables are reported in Table 2. All the predictions are reported at the 95 per cent level of confidence.

Table 2 indicates that with the CE1, work discretion score as the dependent variable, three of the independent work variables entered the prediction with a common variance of 22,54 per cent in the dependent variable. Intrinsic job satisfaction explained the largest part of the prediction 20,20 per cent. Although individually significant, the two market orientation scales of intelligence generation and responsiveness formed only 2,34 per cent of the total prediction of 22,54 per cent. With the CE2 management support and risk acceptance scale as dependent variable, four of the management subscales entered the prediction model with a prediction of 25,09 per cent in the dependent variable. The first variable, market orientation intelligence generation, formed 14,26 per cent of the prediction with formality (F1), responsiveness (MO3) and authoritarianism (F2) respectively contributing 4,70, 3,49 and 2,64 to the prediction. Only two work sub-scales (extrinsic job satisfaction and responsiveness) entered the CE3 rewards/reinforcement prediction with a common variance of 40,33 per cent in the dependent variable. The innovative initiatives CE4 sub-scale had a 35,92 per cent common variance with four of the independent variables. The responsiveness market orientation and extrinsic job satisfaction sub-scales formed the largest part of the prediction, followed by formality (flexibility). The financial support CE 5 sub-scale had a weak predication of only 13,69 per cent, with only responsiveness as market orientation and formality as flexibility entering the prediction. Due to this low prediction, a Structural Equations Model was not built. With the CE6 sufficient time sub-scale as dependent variable, none of the independent work variables met the 0,05 significance level for entry into the model. The C7 (organisational boundaries) sub-scale was predicted by 19,91 per cent with extrinsic job satisfaction and intelligence generation market orientation respectively contributing 16,09 and 3,85 per cent. This low prediction did not justify the building of a Structural Equations model. Inadequate time (CE8) as dependent variable had a weak prediction of only 5,73 per cent with both the extrinsic and intrinsic job satisfaction scales respectively contributing only 2,71 and 3,02 per cent in the dependent variable. The prediction was too low to justify the building of a structural equations model.

Only four of the eight corporate entrepreneurship sub-scales were predicted reasonably well. For this reason only four Structural Equation Models were built to investigate the prediction in the dependent variables. The strength of Structural Equation Modelling lies in its ability to measure the simultaneous inter-related dependent relationships between latent (unobserved) and manifest (observed) variables (Boshoff, 2009). A Structural Equations Model with CE1, work discretion as outcome variable is presented in Figure 2.

The path coefficients in Figure 2 are moderate $>0,3$ to large $>0,5$. Confirmatory Factor Analysis for this model shows a reasonable fit with the data with a Goodness of Fit Index $(\mathrm{GFI})=0,8523$, GFI Adjusted for Degrees of Freedom $(\mathrm{AGFI})=0,8216$, Root Mean Square Residual $(\mathrm{RMR})=$ 0,0605 , Chi-square $(\mathrm{df}=269, \mathrm{p}>$ Chi-square $<0,0001)=$ 720,5685 , RAMSEA Estimate $(90 \% \mathrm{Cl} 0,0649$ to $0,0774=$ 0,0771, Bentler's Comparative Fit Index $=0,8408$ and Bollen (1988) Non-normed Index Delta2 $=0,8426$.

The prediction of management support and risk acceptance (CE2) was further investigated by means of the Structural Equations Model seen in Figure 3. 
Table 1: Pearson product moment correlations for corporate entrepreneurship and variables of market orientation, job satisfaction and flexibility $(\mathbf{N}=\mathbf{3 3 3})$

\begin{tabular}{l|l|l|l|l|l|l|l|c}
\hline Variable & CE1 & CE2 & CE3 & CE4 & CE5 & CE6 & CE7 & CE8 \\
\hline MO1 & 0,262 & 0,378 & 0,327 & 0,327 & 0,229 & $-0,034$ & $-0,327$ & 0,057 \\
& 0,0001 & 0,0001 & 0,0001 & 0,0001 & 0,0001 & 0,5393 & 0,0001 & 0,2964 \\
\hline MO2 & $-0,067$ & $-0,225$ & $-0,230$ & $-0,463$ & $-0,261$ & 0,025 & 0,226 & $-0,109$ \\
& 0,2261 & 0,0001 & 0,0001 & 0,0001 & 0,0001 & 0,6550 & 0,0001 & 0,0479 \\
\hline MO3 & 0,027 & 0,337 & 0,251 & 0,843 & 0,347 & $-0,016$ & $-0,156$ & $-0,042$ \\
& 0,6186 & 0,0001 & 0,0001 & 0,0001 & 0,0001 & 0,7780 & 0,0001 & 0,4498 \\
\hline F1 & 0,259 & 0,334 & 0,285 & 0,335 & 0,209 & $-0,025$ & $-0,257$ & $-0,027$ \\
& 0,0001 & 0,0001 & 0,0001 & 0,0001 & 0,0001 & 0,6479 & 0,0001 & 0,6247 \\
\hline F2 & $-0,219$ & $-0,236$ & $-0,259$ & $-0,233$ & $-0,144$ & $-0,001$ & 0,057 & $-0,111$ \\
& 0,0001 & 0,0001 & 0,0001 & 0,0001 & 0,0085 & 0,9790 & 0,0001 & 0,0427 \\
\hline JS1 & 0,449 & 0,290 & 0,623 & 0,357 & 0,155 & 0,069 & $-0,401$ & 0,165 \\
& 0,0001 & 0,0001 & 0,0001 & 0,0001 & 0,0047 & 0,2080 & 0,0001 & 0,0026 \\
\hline JS2 & 0,341 & 0,189 & 0,438 & 0,293 & 0,164 & $-0,043$ & $-0,296$ & $-0,035$ \\
& 0,0001 & 0,0005 & 0,0001 & 0,0001 & 0,0027 & 0,4355 & 0,0001 & 0,0529 \\
\hline
\end{tabular}

$\mathrm{CE}=$ corporate entrepreneurship; CE1 = work discretion; CE2 = management support and risk acceptance; CE3 = rewards/reinforcement; CE4 = innovative initiatives; $\mathrm{CE} 5=$ financial support; $\mathrm{CE} 6=$ sufficient time; $\mathrm{CE} 7=$ organisational boundaries; $\mathrm{CE} 8=$ inadequate time; $\mathrm{MO}$ = market orientation; $\mathrm{MO} 1=$ intelligence generation; $\mathrm{MO} 2=$ inertia; $\mathrm{MO} 3$ = responsiveness; $\mathrm{F}=$ flexibility; $\mathrm{F} 1=$ formality; $\mathrm{F} 2=$ authoritarianism; JS = job satisfaction; JS1 = extrinsic; JS2 = intrinsic

Table 2: Results of multiple regression analysis with CE1, CE2, CE3, CE4, CE5, CE6, CE7 and CE8 as the dependent variables

\begin{tabular}{|c|c|c|c|c|}
\hline Variable & $\mathbf{F}(\mathbf{d f})$ & $\boldsymbol{P}$ & $\mathbf{R}^{2}$ & $\mathbf{C}(\mathbf{p})$ \\
\hline \multicolumn{5}{|c|}{ (CE1) work discretion } \\
\hline JS1 & $83,79(1 ; 332)$ & 0,0001 & 0,2020 & 16,1612 \\
\hline MO1 & $4,85(2 ; 331)$ & 0,0284 & 0,2136 & 13,1649 \\
\hline $\mathrm{MO} 3$ & $5,01(3 ; 330)$ & 0,0259 & 0,2254 & 10,0616 \\
\hline \multicolumn{5}{|c|}{ (CE2) management support } \\
\hline MO1 & $55,03(1 ; 332)$ & 0,0001 & 0,1426 & 45,2903 \\
\hline F1 & $19,15(2 ; 331)$ & 0,0001 & 0,1896 & 26,7649 \\
\hline MO3 & $14,80(3 ; 330)$ & 0,0001 & 0,2245 & 13,5351 \\
\hline $\mathrm{F} 2$ & $11,57(4 ; 329)$ & 0,0008 & 0,2509 & 3,9959 \\
\hline \multicolumn{5}{|c|}{ (CE3) rewards/reinforcement } \\
\hline JS1 & $210,22(1 ; 332)$ & 0,0001 & 0,3884 & 9,6219 \\
\hline MO3 & $8,21(2 ; 331)$ & 0,0044 & 0,4033 & 3,3993 \\
\hline \multicolumn{5}{|c|}{ (CE4) innovative initiatives } \\
\hline $\mathrm{MO} 3$ & $100,95(1 ; 332)$ & 0,0001 & 0,2337 & 64,4358 \\
\hline JS1 & $32,11(2 ; 331)$ & 0,0001 & 0,3017 & 31,5503 \\
\hline $\mathrm{MO} 2$ & $19,69(3 ; 330)$ & 0,0001 & 0,3411 & 13,2988 \\
\hline F1 & $9,25(4 ; 329)$ & 0,0025 & 0,3592 & 6,0183 \\
\hline \multicolumn{5}{|c|}{ (CE5) financial support } \\
\hline $\mathrm{MO3}$ & $45,34(1 ; 332)$ & 0,0001 & 0,1205 & 9,2041 \\
\hline F1 & $6,27(2 ; 331)$ & 0,0128 & 0,1369 & 4,9021 \\
\hline \multicolumn{5}{|c|}{$\begin{array}{c}\text { (CE6) sufficient time } \\
\text { No entries }\end{array}$} \\
\hline \multicolumn{5}{|c|}{ (CE7) organizational boundaries } \\
\hline JS1 & $63,34(1 ; 332)$ & 0,0001 & 0,1606 & 19,6187 \\
\hline MO1 & $15,87(2 ; 331)$ & 0,0001 & 0,1991 & 5,6242 \\
\hline \multicolumn{5}{|c|}{ (CE8) inadequate time } \\
\hline JS1 & $9,23(1 ; 332)$ & 0,0001 & 0,0271 & 15,2254 \\
\hline JS2 & $20,56(2 ; 331)$ & 0,0001 & 0,0573 & 6,5496 \\
\hline
\end{tabular}




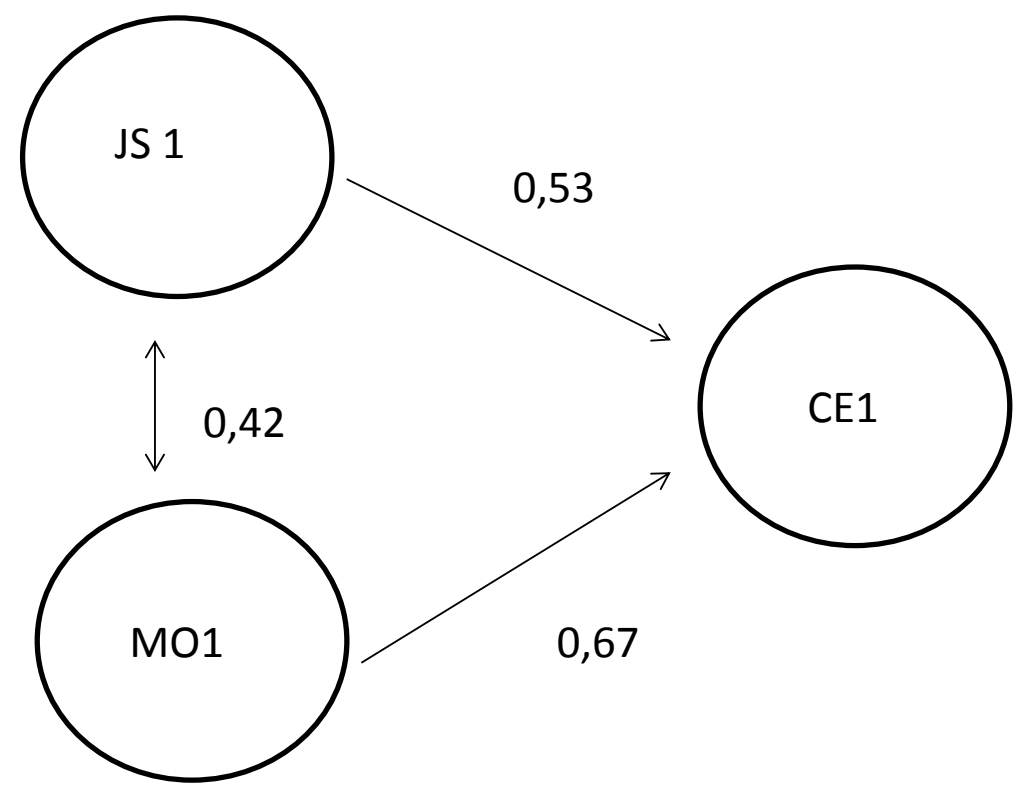

Figure 2: Structural Equations Model with the corporate entrepreneurship sub-scale of work discretion as outcome

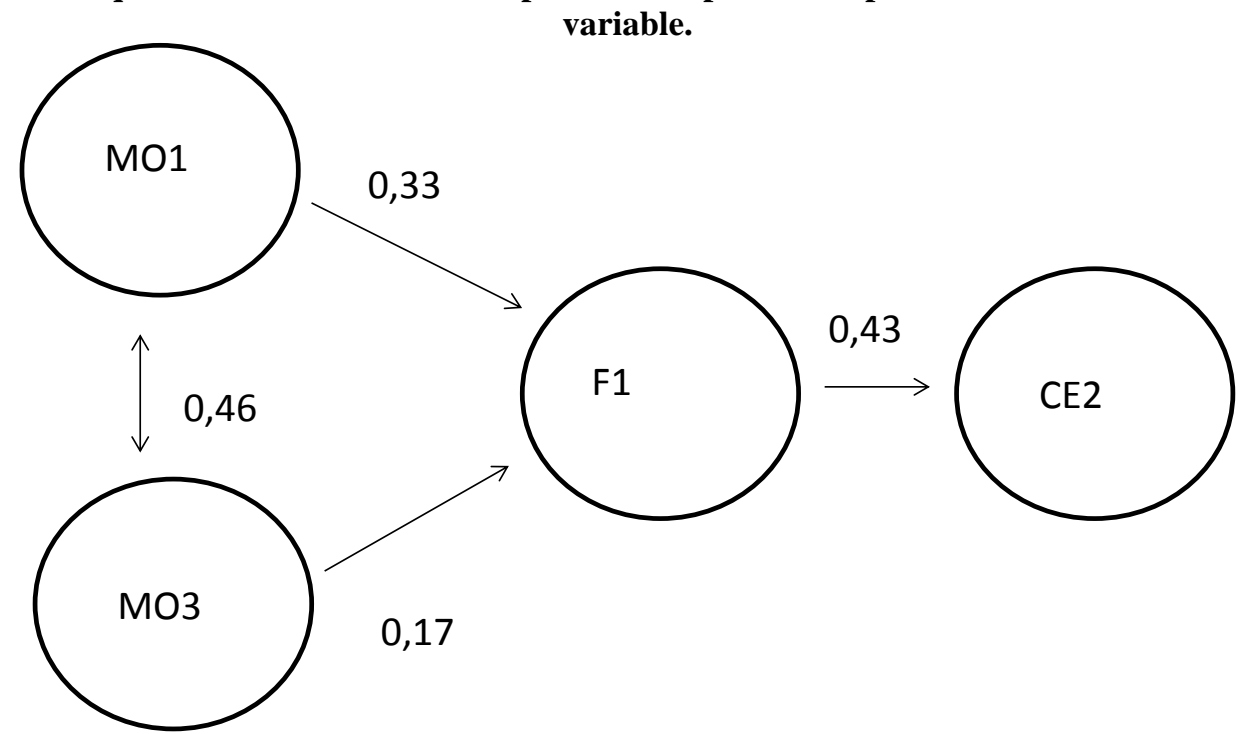

Figure 3: Structural Equations Model with the corporate entrepreneurship sub-scale of management support as outcome variable.

The Structural Equations Model in Figure 3 shows an insignificant $(0,17)$ to moderate (between 0,33 and 0,46$)$ fit with the data. Confirmatory Factor Analysis for this model shows a reasonable fit with the data with a Goodness of Fit Index $(\mathrm{GFI})=0,8622$, GFI Adjusted for Degrees of Freedom $(\mathrm{AGFI})=0,8337$, Root Mean Square Residual $(\mathrm{RMR})=0,0785$, Chi-square $(\mathrm{df}=291, \mathrm{p}>$ Chi-square < $0,0001)=677,1927$, RAMSEA Estimate $(90 \% \mathrm{Cl} 0,0570$ to $0,0694=0,0632$, Bentler's Comparative Fit Index $=0,8459$ and Bollen (1988) Non-normed Index Delta2 $=0,8515$.

The Structural Equations Model with rewards/reinforcement (CE 3) as dependent variables is reported in Figure 4.

The Structural Equations Model in Figure 4 indicates insignificant $(<0,2)$, small $(0,27)$ and large $(0,76)$ effects. The indices of the Confirmatory Factor Analysis shows a reasonable fit with the data: Goodness of Fit Index $(\mathrm{GFI})=$ 0,8615 , GFI Adjusted for Degrees of Freedom $(\mathrm{AGFI})=$ 0,8078 , Root Mean Square Residual $(\mathrm{RMR})=0,0607$, Chi- square $(\mathrm{df}=98, \mathrm{p}>$ Chi-square $<0,0001)=398,9594$, RAMSEA Estimate $(90 \% \mathrm{Cl} 0,0856$ to $0,1061=0,0962$, Bentler's Comparative Fit Index $=0,8459$ and Bollen (1988) Non-normed Index Delta2 $=0,8476$.

The Structural Equations Model for the prediction of innovative initiatives (CE4) is shown in Figure 5.

The indices of the Structural Equations Model in Figure 5 shows a moderate fit with the data. Confirmatory Factor Analysis shows an acceptable fit with the data: Goodness of Fit Index $(\mathrm{GFI})=0,8304$, GFI Adjusted for Degrees of Freedom $(\mathrm{AGFI})=0,8001$, Root Mean Square Residual $(\mathrm{RMR})=0,0751$, Chi-square $(\mathrm{df}=369, \mathrm{p}>$ Chi-square < $0,0001)=983,2179$, RAMSEA Estimate $(90 \% \mathrm{Cl} 0,0655$ to $0,0762=0,0708$, Bentler's Comparative Fit Index $=0,8088$ and Bollen (1988) Non-normed Index Delta2 $=0,8110$. 


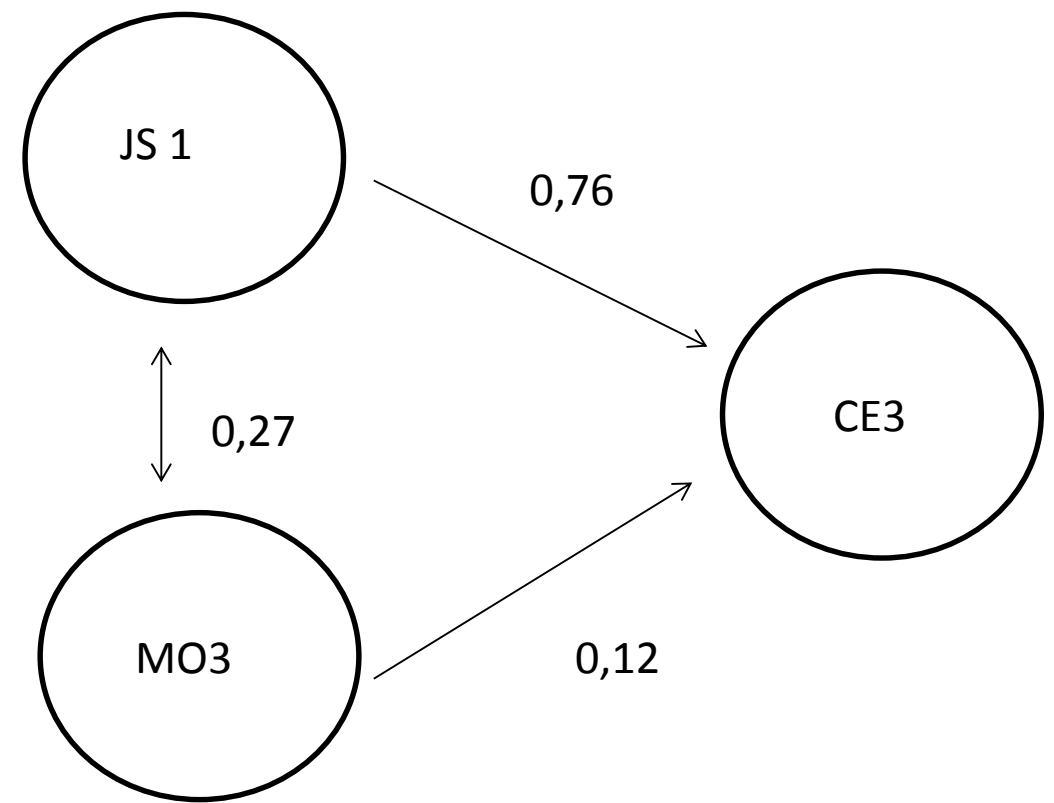

Figure 4: Structural equations model with the corporate entrepreneurship sub-scale of rewards/reinforcement as outcome variable.

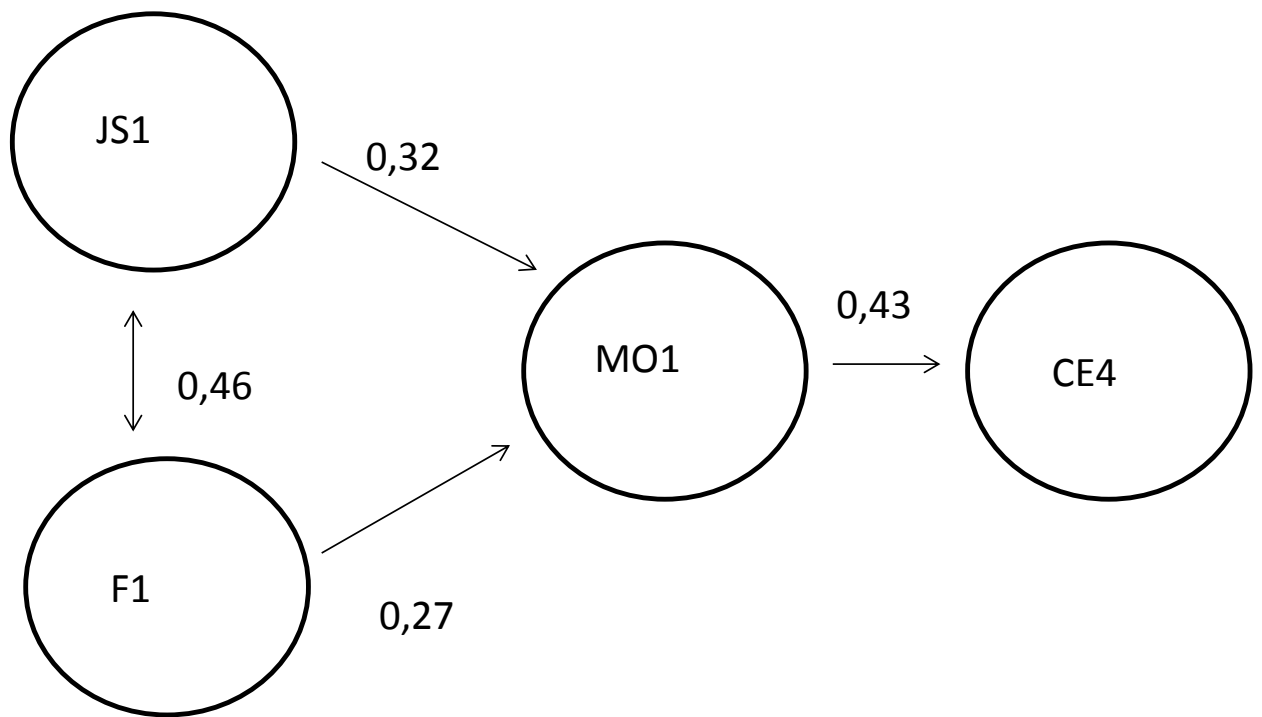

Figure 5: Structural equations model with the corporate entrepreneurship sub-scale of innovative initiatives as outcome variable.

\section{Discussion}

The results of this study emphasise the important relationships of market orientation, flexibility and job satisfaction with corporate entrepreneurship. A refinement of the regression of the different independent variables on the eight corporate entrepreneurial sub-scales as dependent variables indicate that only the sixth subscale, sufficient time, was not predicted by the different independent variables. Our study supports the relationships conceptualised in Figure 1 with the exception of sufficient time, which had no significant correlation or prediction at the 95 per cent level of confidence. The findings confirm the arguments that the different market orientation, flexibility and job satisfaction sub-scales are important factors to take into consideration in the nurturing of corporate entrepreneurship and sustaining global competitiveness. The current study emphasizes the important role that management plays in establishing and maintaining a competitive corporate entrepreneurial environment by nurturing market orientation, flexibility and job satisfaction practices.

Management should take cognisance of the negative relationship of the market orientation sub-scale of inertia to most of the corporate entrepreneurial variables. The market orientation sub-scales intelligence generation (MO1) and responsiveness (MO3), show a significant positive relationship to five and four of the corporate entrepreneurial sub-scales respectively. This is similar to the findings by Baker and Sinkula (2009) as well as Barrett et al. (2012) that a significant positive relationship exists between market orientation and entrepreneurship. It is important to note that the organizational boundaries sub-scale (CE7) has a significant negative relationship with intelligence generation (MO1) and responsiveness to the market (MO3). The 
significant negative relationships with organisational boundaries (CE7) should serve as a warning to management that inflexible management practices have negative associations with market orientation variables. By applying a proactive market orientation and aligning it with corporate entrepreneurial practices should secure competitiveness (Kumar et al., 2011), as well as boost innovativeness (Renko et al., 2009), performance (Bojica et al., 2011) and profitability of an organisation (Baker \& Sinkula, 2009).

The flexibility sub-scales formality (F1) has significant positive relationships with five of the corporate entrepreneurial subscales, while authoritarianism (F2) has mainly significant negative relationships with the same five corporate entrepreneurial sub-scales. This implies that formal structures that support flexible reactions, foster corporate entrepreneurial actions. On the other hand, the strict rigid structures of inflexible authoritarianism inhibit corporate entrepreneurial behaviour. Management should note that inflexibility implicated the organisational boundaries subscale (CE7) significantly negatively relates to formality, but is positively related to authoritarianism. The monitoring of flexible management practices is essential in the reaction to customer needs (Enderwick \& Ronanyne, 2004) to maintain innovativeness (Barrett et al., 2012; Jaworski \& Kohli, 1996; Van de Ven \& Poole, 1995) and pervade cross-functional boundaries (Miles \& Snow, 1978; Child \& McGrath, 2001) as well as securing market performance (Barrett et al., 2012; Olalekan, 2011). Management should take cognisance of the fact that flexible operations contribute to corporate resilience by creating dynamic environments (Ignatiadis, 2007; Koornhof, 2001) and international competitiveness (Georgoulias et al., 2009; Ireland et al., 2003; Hitt et al., 1998).

Similar to the findings of previous studies (Akehurst et al., 2009; Antoncic \& Antoncic, 2011b; Comeche \& Loras, 2010; Kuratko et al., 2005) extrinsic and intrinsic job satisfaction sub-scales showed a significant positive relationship with five of the corporate entrepreneurial subscales and a significant negative relationship with the inflexible management practices implicated by the organisational boundaries sub-scale (CE7). The current findings is in accordance with the findings of Kuratko et al. (2005) that job satisfaction contributes to entrepreneurial actions, which ultimately leads to organizational growth (Akehurst et al., 2009; Antoncic \& Antoncic, 2011a). It is further important for management to note the central role that job satisfaction plays in the over-all wellbeing of an organization (Spector, 2008) and implicitly contributing to the stimulation of intrapreneurship (Akehurst et al., 2009).

\section{Managerial implications}

The globalisation of markets requires swift reaction to warrant a competitive advantage and superior performance. Management should support activities that sustain corporate entrepreneurial activities to maintain strategic competitiveness. This study suggests that detailed attention to external job satisfaction, formal flexibility and market orientations facilitate different corporate entrepreneurial activities. Businesses should develop strategies that support these practices that sustain corporate entrepreneurship.
Management should investigate methods to improve and support external job satisfaction, formal flexibility policies and market orientation strategies to meet the demands of corporate entrepreneurial activities. Simultaneously management should guard against inflexible authoritarian practices that inhibit creative corporate entrepreneurial initiatives. The nurturing of these strategies should warrant a competitive advantage.

This study offers important insights for both managers and researchers in the field of corporate entrepreneurship. The study advances our understanding of the influence of market orientation, organisational flexibility and job satisfaction on corporate entrepreneurship. An increased understanding of the relationship of these work variables with corporate entrepreneurship offers management a more solid foundation on which to base decisions on.

Corporate entrepreneurial conditions could have a substantial direct influence on the growth and survival of a business and indirectly on the economy as a whole. Policy makers in decision-making processes should take the factors that contribute to the functioning of corporate entrepreneurship in a business into account. Business management should bear in mind the importance of the market orientation, flexibility and job satisfaction factors in planning strategies to advance corporate entrepreneurship.

\section{Limitations of the current study and implications for future research}

The results of the current study are viewed in the light of its limitations. Firstly, the sample comprises of only South African based businesses. Therefore, findings may not be generalisable to other countries. The findings can also only be generalised to organisations represented in the sample. A reproduction of the current study in other business sectors and in other countries is recommended. As indicated by Spector (1987), common method variance and response bias could negatively influence the findings of the current study due to its self-report method.

In order to gain a better understanding of the complexity of the different work variables and its influence on corporate entrepreneurship, future research should investigate alternative variables related to corporate entrepreneurship. A broader framework of the relationship of different work variables with corporate entrepreneurship should offer better insight to policy makers to improve a corporate entrepreneurship climate. Future investigations should strive to identify the influence of additional internal organisational variables on corporate entrepreneurship. The integration of a variety of internal organisational factors that positively influence corporate entrepreneurship should broaden the conceptual framework on which management can base decisions.

\section{Conclusion}

The ultimate aim of businesses is to invest in their performance. This paper integrates the processes and interactions involved between market orientation, flexibility 
and job satisfaction in facilitating corporate entrepreneurship. The findings give a closer understanding of the individual contributions of the market orientation, flexibility and job satisfaction factors to corporate entrepreneurship. The results of this study can be used by management to advance corporate entrepreneurial practices. A continuous seeking of opportunities to nourish and prolong sustainable corporate entrepreneurship should be investigated.

\section{References}

Akehurst, G., Comeche, J.M. \& Galindo, M. 2009. 'Job satisfaction and commitment in the entrepreneurial SME', Small Business Economics, 32(3): 277-289.

Antoncic, J.A. \& Antoncic, B. 2011a. 'Employee satisfaction, intrapreneurship and firm growth: A model', Industrial Management \& Data Systems, 111(4): 589-607.

Antoncic, J.A. \& Antoncic, B. 2011b. 'General employee satisfaction, corporate entrepreneurship, and growth of companies: An empirical study in Slovenia', International Leadership Journal, 3(1): 3-19.

Antoncic, B. \& Hisrich, R.D. 2001. 'Intrapreneurship: Construct refinement and cross-cultural validation', Journal of Business Venturing, 16: 495-527.

Atuahene-Gima, K., Slater, S.F. \& Olson, E.M. 2005. 'The contingent value of responsive and proactive market orientations for new product program performance', Journal of Product Innovation Management, 22(6): 464-482.

Baker, W.E. \& Sinkula, J.M. 2009. 'The complementary effects of market orientation and entrepreneurial orientation on profitability in small businesses', Journal of Small Business Management, 47(4): 433-464.

Barrett, H., Balloun, J.L. \& Weinstein, A. 2009. 'How variation in management perceptions affects organizational performance', Quality \& Quantity, 43: 451-461.

Barrett, H., Balloun, J.L. \& Weinstein, A. 2012. 'Creative climate: A critical success factor for $21^{\text {st }}$ century organisations', International Journal of Business Innovation and Research, 6(2): 202-219.

Barrett, H. \& Weinstein, A. 1997. 'Corporate entrepreneurship, the marketing mix, and business performance', Conference of the Academy of Marketing Science, 20: 144-150.

Bhardwaj, B.R., Sushil, S. \& Momaya, K. 2007. 'Corporate entrepreneurship: Application of moderator method', Singapore Management Review, 29(1): 47-58.

Bhattacharya, M. \& Giapponi, C.C. 2007. 'Outlay flexibility and organisational risk: Examining the relationship and its implication for firm returns', International Journal of Risk Assessment and Management, 7(4): 461-473.
Bojica, A.M., Del Mar Fuentes, M. \& Gomez-Gras, J.M. 2011. 'Radical and incremental entrepreneurial orientation: The effect of knowledge acquisition', Journal of Management and Organization, 17: 326-343.

Bolton, D.L. \& Lane, M.D. 2012. 'Individual entrepreneurial orientation: Development of a measurement instrument', Education and Training, 54(2/3): 1-20.

Boshoff, C. 2009. 'A psychometric assessment of an instrument to measure a service firm's customer-based corporate reputation', South African Journal of Business Management, 40(2): 35-44.

Buganza, T., Gerst, M. \& Verganti, R. 2010. 'Adoption of NPD flexibility practices in new technology-based firms', European Journal of Innovation Management, 13(1): 62-80.

Cambra-Fierro, J.J., Hart S., Polo-Redondo, Y. \& FusterMur, A. 2012. 'Market and learning orientation in times of turbulence: Relevance questioned? An analysis using a multi-case study', Quality \& Quantity, 46: 855-871.

Castrogiovanni, G.J., Urbano, D. \& Loras, J. 2011. 'Linking corporate entrepreneurship in human resource management in SMEs', International Journal of Manpower, 32(1): 34-47.

Child, J. \& McGrath, R.G. 2001. 'Organisations unfettered: Organisational form in an information-intensive economy', Academy of Management Journal, 44(6): 1135-1148.

Chung, L.H. \& Gibbons, P.T. 1997. 'Corporate entrepreneurship. The roles of ideology and social capital', Group Organization Management, 22(1): 10-30.

Comeche, J.M. \& Loras, J. 2010. 'The influence of variables of attitude on collective entrepreneurship', International Entrepreneurship Management Journal, 6: 23-38.

Cooper, C.R. \& Schindler, P.S. 2008. Business research methods. $10^{\text {th }}$ Edition. Boston, MA: McGraw-Hill.

Covin, J.G., Green, K.M. \& Slevin, D.P. 2006. 'Strategic process effects on the entrepreneurial orientation-sales growth rate relationship', Entrepreneurship Theory and Practice, 30: 57-81.

Diener, E., Emmons, R.A., Larsen, R.J. \& Griffin, S. 1985. 'The satisfaction with life scale', Journal of Personality Assessment, 49: 71-75.

Drucker, P.F 2007. Innovation and entrepreneurship. $2^{\text {nd }}$ Edition. Burlington, MA: Butterworth-Heinemann.

Enderwick, P. \& Ronayne, E. 2004. 'Reconciling entrepreneurship and organisational structure in international operations: Evidence from New Zealand specialist food exporters', Journal of Asia Pacific Marketing, 3(2): 53-68.

Fontannaz, S. \& Oosthuizen, H. 2007. 'The development of a conceptual framework to guide sustainable organisational 
performance', South African Journal of Business Management, 38(4): 9-19.

Galup, S.D., Klein, G. \& Jiang, J.J. 2008. 'The impact of job characteristics on employee satisfaction: A comparison between permanent and temporary employees', Journal of Computer Information Systems, 48(4): 58-68.

Georgoulias, K., Papakostas, N., Chryssolouris, G., Stanev, S., Krappe, H. \& Ovtcharova, J. 2009. 'Evaluation of flexibility for the effective change management of manufacturing organizations', Robotics and ComputerIntegrated Manufacturing, 25: 888-893.

Goodale, J.C., Kuratko, D.F., Hornsby, J.S. \& Covin, J.F. 2011. 'Operations management and corporate entrepreneurship: The moderating effect of operations control on the antecedents of corporate entrepreneurial activity in relation to innovation performance', Journal of Operations Management, 29: 116-127.

Goosen, C.J., De Coning, T.J. \& Smit, E.v.d.M. 2002a. 'Corporate entrepreneurship and financial performance: The role of management', South African Journal of Business Management, 33(4): 21-27.

Goosen, C.J., De Coning, T.J. \& Smit, E.v.d.M. 2002b. 'The development of a factor based instrument to measure corporate entrepreneurship: A South African perspective', South African Journal of Business Management, 33(3): 3949.

Guth, W.D. \& Ginsberg, A. 1990. 'Corporate entrepreneurship', Strategic Management Journal, 11: 5-15.

Hart, S. (Ed.). 2003. Marketing changes. London: Thomson.

Heil, D., Maxwell, T. \& Whittaker, L. 2003. 'Towards the very nature of corporate strategy', South African Journal of Business Management, 34(1): 1-11.

Hitt, M.A., Ireland, R.D., Camp, S.M. \& Sexton, D.L. 2002. Strategic entrepreneurship: Integrating entrepreneurial and strategic management perspectives. In Hitt, M.A., Ireland, R.D., Camp S.M. \& Sexton, D.L. (Eds.). Strategic entrepreneurship: Creating a new integrated mindset. Oxford: Blackwell.

Hitt, M.A., Keats, B.W. \& DeMarie, S.M. 1998. 'Navigating in the new competitive landscape: Building strategic flexibility and competitive advantage in the $21^{\text {st }}$ century', Academy of Management Executive, 12(4): 22-42.

Hornsby, J.S., Holt, D.T. \& Kuratko, D.F. 2008. 'The dynamic nature of corporate entrepreneurship: Assessing the CEAI', Academy of Management Proceedings, 1-6.

Hornsby, J.S., Kuratko, D.F. \& Zahra, S.A. 2002. 'Middle managers' perception of the internal environment for corporate entrepreneurship: Assessing a measurement scale', Journal of Business Venturing, 17: 253-273.
Hornsby, J.S. \& Naffziger, D.W., Kuratko, D. \& Montagno, R. 1993. 'An interactive model of the corporate entrepreneurship process', Entrepreneurship Theory and Practice, 17(2): 29-37.

Horwitz, F.M., Allan, C., Brosnan, P. \& Walsh, P. 2000. 'Flexible work practices: Perspectives from the southern hemisphere', South African Journal of Business Management, 31(2): 76-83.

Hoskisson, R.E. \& Busenitz, L.W. 2002. 'Market uncertainty and learning distance in corporate entrepreneurship entry mode choice'. In Hitt, M.A., Ireland, R.D., Camp S.M. \& Sexton D.L. (Eds.). Strategic entrepreneurship: Creating a new integrated mindset. Oxford: Blackwell.

Ignatiadis, I. 2007. 'The impact of enterprise systems or organizational resilience', Journal of Information Technology, 22: 36-43.

Ireland, R.D., Hitt, M.A. \& Sirmon, D.G. 2003. 'A model of strategic entrepreneurship: The construct and its dimensions', Journal of Management, 29(6): 963-989.

Jafari, M., Rezaeenour, J., Mazdeh, M.M. \& Hooshmandi, A. 2011. 'Development and evaluation of a knowledge risk management model for project-based organisations', Management Decision, 49(3): 309-329.

Jaworski, A.K. \& Kohli, B.J. 1990. 'Market orientation: The construct, research propositions, and managerial implications', Journal of Marketing, 54: 1-18.

Jaworski, A.K. \& Kohli, B.J. 1996. 'Market Orientation: Review, refinement, and roadmap', Journal of Market Focused Management, 1: 119-135.

Jimenez-Zarco, A., Martinez-Ruiz, M. \& Izquierdo-Yusta, A. 2011. 'The impact of market orientation dimensions on client cooperation in the development of new service innovations', European Journal of Marketing, 45(1/2): 4367.

Kaiser, R.B. \& Overfield, D.V. 2010. 'Assessing flexible leadership as a mastery of opposites', Consulting Psychology Journal: Practice and Research, 62(2): 105118.

Khandwalla, P.N. 1977. The design of organizations. New York: Harcourt.

Khandwalla, P.N. 1987. 'Generation of pioneeringinnovative management: Some Indian evidence', Organization Studies, 8(1): 39-59.

Kohli, A.K. \& Jaworski, B.J. 1990. 'Market orientation: The construct, research propositions, and managerial implications', Journal of Marketing, 54(2): 1-18.

Kohli, A.K., Jaworski, B.J. \& Kumar, A. 1993. 'Markor: A measure of market orientation', Journal of Marketing Research, 30(4): 467-477. 
Koornhof, C. 2001. 'Developing a framework for flexibility within organisations', South African Journal of Business Management, 32(4): 21-29.

Kukalis, S. 1989. 'The relationship among firm characteristics and design strategic planning in large organizations', Journal of Management, 15(4): 565-580.

Kumar, V., Jones, E., Venkatesan, R. \& Leone, R.P. 2011. 'Is market orientation a source of sustainable competitive advantage or simply the cost of competing?', Journal of Marketing, 75: 16-30.

Kumar, V., Subramanian, R. \& Strandholm, K. 2003. 'Market orientation and performance: Does organizational strategy matter?', Journal of Applied Business Research, 18(1): 37-49.

Kuratko, D.F. 2011. 'Entrepreneurship theory, process, and practice in the $21^{\text {st }}$ century', International Journal of Entrepreneurship and Small Business, 13(1): 8-17.

Kuratko, D.F. 2009. 'The entrepreneurial imperative of the $21^{\text {st }}$ century', Business Horizons, 52(5): 421-428.

Kuratko, D.F., Hornsby, J.S. \& Bishop, J.W. 2005. 'Managers' corporate entrepreneurial actions and job satisfaction', International Entrepreneurship and Management Journal, 1: 275-291.

Lee, S.M., Peris-Ortiz, M. \& Fernández-Guerrero, R. 2011. 'Corporate entrepreneurship and human resource management: Theoretical background and a case study', International Journal of Manpower, 32(1): 48-67.

Leibold, M., Voelpel, S.C. \& Tekie, E.B. 2004. 'Managerial levers in cultivating new mental space for business innovation', South African Journal of Business Management, 35(4): 61-71.

Li, Y., Zhao, Y., Tan, J. \& Liu, Y. 2008. 'Moderating effects of entrepreneurial orientation on market orientationperformance linkage: Evidence from Chinese small firms', Journal of Small Business Management, 46(1): 113-133.

Locke, E.A. 1976. 'What is job satisfaction?', Organizational Behaviour and Human Performance, 4: 309336.

Loubser, S.S. 2000. 'The relationship between a market orientation and financial performance in South African organisations', South African Journal of Business Management, 31(2): 84-90.

Lumpkin, G.T. \& Dess, G.G. 1996. 'Clarifying the entrepreneurial orientation construct and linking it to performance', Academy of Management Review, 21: 135172.

Maatoofi, A.R. \& Tajeddini, K. 2011. 'Effect of marketing orientation and entrepreneurial orientation on innovation', Journal of Management Research, 11(1): 20-30.
Merlo, O. \& Auh, S. 2009. 'The effects of entrepreneurial orientation, market orientation, and marketing subunit influence on firm performance', Marketing Letters, 20(3): 295-311.

Miles, M.P. \& Darroch, J. 2006. 'Large firms, entrepreneurial marketing processes, and the cycle of competitive advantage', European Journal of Marketing, 40(5/6): 485-501.

Miles, R.E. \& Snow, C. 1978. Organizational strategy and process. New York: McGraw- Hill.

Morris, M.H. \& Kuratko, D.F. 2002. Corporate entrepreneurship. New York: Harcout.

Morris, M.H., Kuratko, D.F. \& Covin, J.G. 2008. Corporate entrepreneurship innovation. $2^{\text {nd }}$ Edition. Mason, $\mathrm{OH}$ : Thomson.

Ngamsirijit, W. 2010. 'Understanding the linkages between flexibility strategy and innovation', World Review of Entrepreneurship, Management and Sustainable Development, 6(1-2): 135-148.

O'Connor, A. \& Yamin, S. 2011. 'Innovation and entrepreneurship: Managing the paradox of purpose in business model innovation', International Journal of Learning and Intellectual Capital, 8(3): 239-255.

Oke, A. 2005. 'A framework for analysing manufacturing flexibility', International Journal of Operations \& Production Management, 25(10): 973-976.

Olalekan, A. 2011. 'Strategic flexibility and market performance of SMEs in Nigeria', International Journal of Management and Enterprise Development, 10(1): 72-91.

Phan, P.H., Wright, M., Uchasaran, D. \& Tan, W.L. 2009. 'Corporate entrepreneurship: Current research and future directions', Journal of Business Venturing, 24: 197-205.

Renko, M., Carsrud, A. \& Brännback, M. 2009. 'The effect of a market orientation, entrepreneurial orientation, and technological capability on innovativeness: A study of young biotechnology ventures in the United States and in Scandinavia', Journal of Small Business Management, 47(3): 331-369.

Rundh, B. 2011. 'Linking flexibility and entrepreneurship to the performances of SMEs in export markets', Journal of Manufacturing Technology Management, 22(3): 330-347.

Sharma, P. \& Chrisman, J.J. 1999. 'Toward a reconciliation of the definitional issues in the field of corporate entrepreneurship', Entrepreneurship Theory Practice, 23(3): 11-27.

Slater, S.F. \& Narver, J.C. 1994. 'Does competitive environment moderate the market orientation-performance relationship?', Journal of Marketing, 58(1): 46-55. 
Spector, P. 1987. 'Method variance is an artefact in self reported affect and perceptions at work: Myth or significant problem?', Journal of Applied Psychology, 72(3): 438-443.

Spector, P. 1997. Job satisfaction: Application, assessment, causes and consequences. Thousand Oaks, CA: Sage.

Spector, P. 2008. Industrial and organisational behaviour. $5^{\text {th }}$ Edition. Hoboken, NJ: John Wiley \& Sons.

Van de Ven, A.H. \& Poole, M.S. 1995. 'Explaining development and change in organisations', Academy of Management Review, 20: 510-540.

Van Wyk, R. \& Boshoff, A.B. 2004. 'Entrepreneurial attitudes: A distinction between two professional groups', South African Journal of Business Management, 35(2): 3338.

Van Wyk, R. \& Adonisi, M. 2008. 'The role of entrepreneurial characteristics in predicting job satisfaction', South African Journal of Economic and Management Sciences, 11(4): 391-407.

Van Wyk, R. \& Adonisi, M. 2011. 'An eight-factor solution for the Corporate Entrepreneurship Assessment Instrument', African Journal of Business Management, 5(1): 3047-3055.

Van Zyl, H.J.C. \& Mathur-Helm, B. 2007. 'Exploring a conceptual model, based on the combined effects of entrepreneurial leadership, market orientation and relationship marketing orientation on South Africa's small tourism business performance', South African Journal of Business Management, 38(2): 17-24.

Visser, D.J., De Coning, T.J. \& Smit, E.v.d.M. 2005. 'The relationship between the characteristics of the transformational leader and the entrepreneur in South African SMEs', South African Journal of Business Management, 36(3): 51-63.

Weiss, D.J. Dawis, R., England, G.P. \& Lofquist, L.H. 1967. Manual of the Minnesota satisfaction questionnaire. St. Paul, MN: University of Minnesota.

Welter, F. \& Smallbone, D. 2011. 'Institutional perspectives on entrepreneurship behaviour in challenging environments', Journal of Small Business Management, 49(1): 107-125.

Zachary, M.A., McKenny, A., Short, J.C. \& Payne, G.T. 2011. 'Family business and market orientation: Construct validation and comparative analysis', Family Business Review, 24(3): 233-251.

Zahra, S.A. 1993. 'Environment, corporate entrepreneurship, and financial performance: A taxonomic approach', Journal of Business Venturing, 8: 319-340.

Zahra, S.A. \& Covin, J.G. 1995. 'Contextual influences on the corporate entrepreneurship performance relationship: A longitudinal analysis', Journal of Business Venturing, 10: 43-58.
Zortea-Johnston, E., Darroch, J. \& Matear, S. 2012. 'Business orientations and innovation in small and medium sized enterprises', International Entrepreneurship Management Journal, 8: 145-164. 